\title{
MINERALOGY OF FINE GRAINED ALLUVIUM FROM BOREHOLE U11G, EXPL. 1, NORTHERN FRENCHMAN FLAT AREA, NEVADA TEST SITE
}

By BLAIR F. JONES
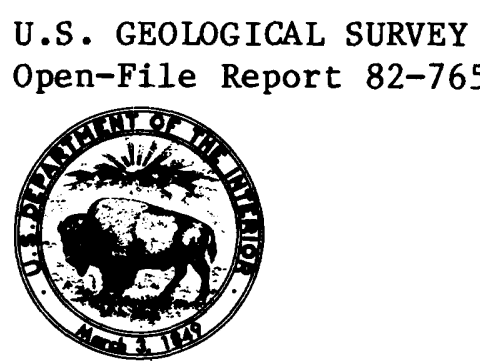
UNITED STATES DEPARTMENT OF THE INTERIOR

JAMES G. WATT, Secretary

GEOLOG ICAL SURVEY

Dallas L. Peck, Director

For additional information write to:

Regional Research Hydrologist

U.S. Geological Survey

432 National Center

Reston, Virginia 22092
Copies of this Open-File Report may be purchased from: Open-File Services Section Branch of Distribution U.S. Geological Survey Denver, Colorado 80225 Phone: (303) 234-5888 


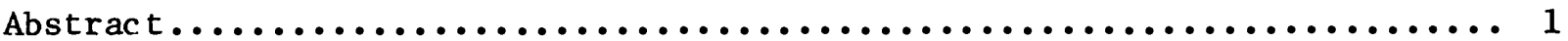

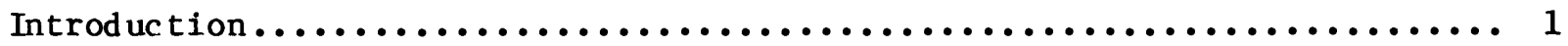

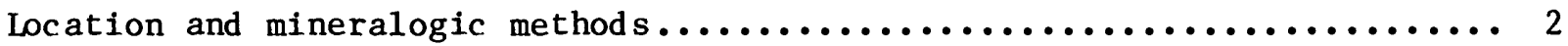

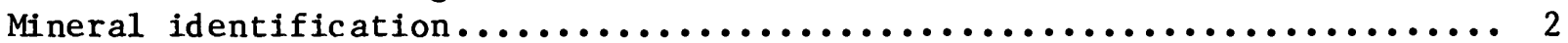

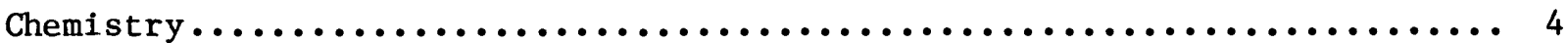

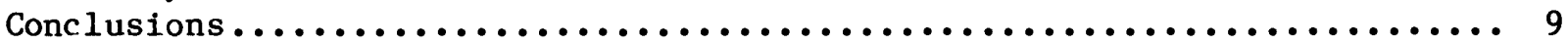

References............................................. 10

ILLUSTRATIONS

Page

Fig. 1. Plot of the anhydrous weight percent ratio of $\mathrm{Fe}_{03}$ to $\mathrm{Al}_{2} \mathrm{O}_{3}$ in $<0.5 \mu \mathrm{m}$ alluvial matrix of borehole $\mathrm{Ul} 1 \mathrm{~g}$, exp1. 1

(table 2) versus the difference in (001) spacing on diffractograms for oriented wet and dry $<1 \mu \mathrm{m}$ clay mineral

fractions. Dots represent samples from at or above $276 \mathrm{~m}$

depth; $x$ 's are for samples from below $276 \mathrm{~m}$ depth.............

TABLES

Page

Table 1. X-ray diffraction mineralogy of alluvial matrix from borehole U11g, expl. 1, north of Frenchman Flat,

Nevada Test Site................................. 3

Table 2. Major element chemical analyses of $<0.5 \mu \mathrm{m}$ alluvial matrix from borehole U11g, North of Frenchman Flat, Nevada

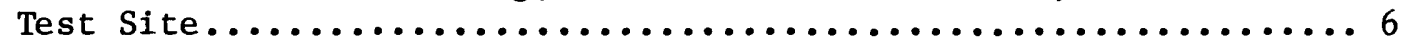

Table 3. Major element chemical analyses and cation exchange capacities of $<0.1 \mu \mathrm{m}$ fractions from selected intervals in core of borehole $\mathrm{Ullg}$, Frenchman Flat, Nevada Test Site......7 
MINERALOGY OF FINE GRAINED ALLUVIUM FROM BOREHOLE U11G, EXPL. 1, NORTHERN FRENCHMAN FLAT AREA, NEVADA TEST SITE

By

Blair F. Jones

\begin{abstract}
The mineralogy of matrix fines in alluvium from borehole $111 \mathrm{~g}$, exp1.1, north of Frenchman Flat, Nevada Test Site, has been examined for evidence of past variations in water table elevation. Although an abundance of zeolite and slightly expanded basal spacings in smectite clays suggest effects of increased hydration of material up to $50 \mathrm{~m}$ above the present water table, these differences might also be related to provenance or environment of deposition. However, the relative uniformity of clay hydration properties in the 50 meters above the current water table suggests long-term stability near the present level, perhaps through most of the Quaternary.
\end{abstract}

\title{
INTRODUCTION
}

Knowledge of the magnitude of water-table rise, of attendant reduction in thickness of the unsaturated zone, and of the resultant shortening of ground-water flow path during Pleistocene pluvial climates is necessary for an evaluation of the Nevada Test Site (NTS) as a waste repository. Winograd and Doty (1980) have indicated that a rise in the potentiometric level within the regional Paleozoic carbonate aquifer of as much as $90 \mathrm{~m}$, but more likely less than $30 \mathrm{~m}$, during Wisconsin time is plausible. This is a report of efforts to use mineralogic criteria to indicate the extent of changes in hydrologic regime in valley fill alluvium at NTS. The nature and mode of occurrence of the relatively uncommon "chain clay" minerals, sepiolite and palygorskite (see summaries in Velde, 1977; Singer, 1979) have suggested that these phases precipitate directly from solution and thus can be indicators of relatively persistent saturation compared to the bulk of the unsaturated zone. Accordingly, in the Amargosa discharge area of the regional carbonate aquifer system underlying the Nevada Test Site (Winograd and Doty, 1980), Papke (1972) and Khoury (1979) have described massive sepiolite as a precipitated phase. Ancient and modern spring deposits attest to the fact that the water table stood for some time at or (as reflected in lake levels) above the land surface. Nearby, Hay and Wiggins (1980) have documented the formation of sepiolite in the calcretes of Kyle Canyon on the flanks of the Spring Mountains under conditions of persistent near-surface soil water levels caused by restricted circulation. Thus it seemed reasonable to postulate that the identification of "chain clays" in the subsurface of valley alluvium at NTS would be indicative of former water table conditions. Further, it was anticipated that textural evidence might corroborate the mineralogic indications. 
The most diagnostic clay fractions were expected in alluvium deposited just far enough away from playa margins to avoid clay minerals deposited under lacustrine conditions. The study required samples which retained the finest finest sediment that were free of contamination by drilling mud. With these criteria in mind, material was obtained and examined from Frenchman Flat boreholes UE5f, UE5n, and Ul1g, exp.1, all of which were drilled to depths greater than the present, nearly flat water table depth (elevation about $735 \mathrm{~m}$ beneath northern Frenchman Flat; Winograd and Thordarson, 1975, fig. 31). On1y borehole U11g, expl. 1 (coordinates N775,758.53, E714,049,641; altitude $\sim 1036$ meters) provided suitable sample over the full depth range of interest. The borehole is situated on the alluvial fan about $6 \mathrm{~km}$ north and near1y $100 \mathrm{~m}$ higher than Frenchman playa and was continuous1y cored with rubber sleeve. The water table is about $300 \mathrm{~m}$ beneath the land surface at this we11 site. The geology of the northern Frenchman Flat area, including seismic surveys, is described by Carr, and others (1975).

Fine sediment of less than 1 millimeter diameter was selected from cored intervals visually representative of distinctive alluvial matrix. From this material small subsamples were lightly ground and pressed in bulk into aluminum holders for $x$-ray diffraction analysis of major mineral composition. For clay mineralogy, $<1 \mu \mathrm{m}$ fractions were separated by centrifuge in deionized water and oriented mounts for X-ray examination were made by smearing on a glass slide. The diffractometer utilized broad-focus $\mathrm{Ni}$ filtered Cu radiation at 45 kilovolts and 20 milliamps, $1^{\circ} 2 \theta$ per minute scans, and a graphite crystal monochromator. A small amount of fine sand in the 75 to $150 \mu \mathrm{m}$ size range was separated by sieving and set aside for later optical examination. The results of $X$-ray diffraction analysis of bulk powders and $<1 \mu \mathrm{m}$ fractions from selected core intervals in borehole $\mathrm{Ul} 1 \mathrm{~g}$, exp1. 1 are summarized in table 1. Table 1 presents quantitative estimates (in parts per ten) for the five principal mineral components of the lower $\mathrm{U1} 1 \mathrm{~g}$, exp1. 1 core obtained through adaptation of the external standard methods of Klug and Alexander (1974) and Schultz (1964) to the X-ray diffraction of randomly oriented bulk powder mounts of the fine alluvial matrix. Clay quantities are estimated from the magnitude of the combined sheet-silicate $02 \&$ reflections near $19^{\circ} 2 \theta$.

Mineral identification

No indication of the "chain" clays sepiolite or palygorskite was present in any of the samples examined. Bulk powders were dominated by quartz, feldspar, zeolite, and (or) calcite, whereas the principal phyllosilicate mineral recognized was most common1y smectite. The on1y zeolite identified by $x$-ray diffraction was clinoptilolite, which persisted into the clay fractions, although a few crystals of other zeolite minerals were noted optically.

The oriented $<1 \mu \mathrm{m}$ clay fraction samples typically produced only 1 to 3 orders of basal (00l) spacings for smectite and commonly a $10 \AA$ reflection on the X-ray diffractograms (as well as reflections for zeolite and perhaps a trace of feldspar). Breadth of smectite diffraction peaks and low $2 \theta$-angle scatter indicated fine particle size and mixed-layering. All smectite (001) reflections expanded to about $17 \AA$ on glycol solvation. Some non-integral variation in higher order basal reflections suggested random interstratification. 
Table 1. X-ray diffraction mineralogy of alluvial matrix from borehole Ullg, expl. 1, north of Frenchman Flat, Nevada Test Site.

\begin{tabular}{|c|c|c|c|c|c|c|c|c|c|}
\hline \multirow[b]{2}{*}{$\begin{array}{l}h(m) \\
\text { wace }\end{array}$} & \multirow[b]{2}{*}{$\begin{array}{c}\text { Core } \\
\text { interval } \\
\text { (m) }\end{array}$} & \multicolumn{4}{|c|}{$\begin{array}{l}\text { bulk powder press mounts } \\
\text { (parts per ten) }\end{array}$} & \multirow[b]{2}{*}{ Clay } & \multicolumn{3}{|c|}{ Oriented $<1 \mu \mathrm{m}$ fractions } \\
\hline & & Quartz & Feld spar & Zeolite & Calcite & & $\begin{array}{l}(001) \text {, in } \AA \\
\text { after wet-dry } \\
\text { cycle }\end{array}$ & $\underset{a / b}{\log }$ & $7 \AA$ \\
\hline .4 & .6 & 1 & 6 & 1 & 0.5 & 1.5 & 13.0 & .91 & -- \\
\hline .2 & .6 & 1 & 5 & .5 & 1.5 & 2 & 13.6 & .90 & $\mathrm{X}$ \\
\hline 4.1 & .5 & 1 & 6 & 1 & 1 & 1 & 13.8 & .54 & $t$ \\
\hline .8 & .1 & 2 & 1 & 2 & 3.5 & 1.5 & 13.2 & .73 & -- \\
\hline 3.1 & -- & 1 & 1.5 & 3 & 2 & 2.5 & 12.6 & .89 & $t$ \\
\hline .6 & .2 & 1.5 & 1.5 & 2 & 3 & 2 & 12.8 & .99 & $\mathrm{X}$ \\
\hline .3 & .2 & 4.5 & 2.5 & .5 & 1 & 1.5 & 13.6 & .85 & -- \\
\hline .5 & .2 & 1.5 & 2 & 2.5 & 2.5 & 1.5 & 13.2 & 1.08 & $x$ \\
\hline 3.3 & .1 & 1.5 & 2 & 2 & 2 & 2.5 & 12.8 & 1.07 & -- \\
\hline .2 & .2 & 1 & 1.5 & 5.5 & 1 & 1 & 12.6 & 0.75 & $\mathrm{X}$ \\
\hline 3.4 & .2 & 1.5 & 2.5 & 3 & 1 & 1.5 & 13.8 & 0.64 & $\mathrm{x}$ \\
\hline .9 & .2 & .5 & 3 & 4 & 1 & 1.5 & 14.0 & 0.70 & $X$ \\
\hline .4 & .2 & 1 & 3 & 3 & 1 & 1 & 13.4 & 0.71 & -- \\
\hline 5.7 & .1 & .5 & 3 & 4 & 1 & 1 & 13.8 & 0.73 & $?$ \\
\hline .5 & .1 & 1.5 & 3 & 4.5 & .5 & .5 & 13.8 & 0.59 & $?$ \\
\hline 1.6 & .15 & 1 & 2 & 2 & 4 & 1 & 13.4 & 0.60 & -- \\
\hline 1.2 & .6 & 1 & 3.5 & 3.5 & 1 & 1.5 & 13.8 & 0.73 & $\mathrm{X}$ \\
\hline 3.0 & .2 & 1 & 2 & 3 & 3 & 1 & 13.8 & 0.83 & $\mathrm{X}$ \\
\hline .6 & .1 & 1 & 3.5 & 1.5 & 3 & 1 & 13.8 & 0.57 & $?$ \\
\hline .3 & .45 & 1 & 2 & 4 & 1 & 2 & 13.6 & 0.79 & $?$ \\
\hline$i .9$ & .1 & 1.5 & 1.5 & 4.5 & 1.5 & 2 & 13.6 & 0.69 & $?$ \\
\hline 1.8 & .3 & 2 & 4 & 3 & .5 & .5 & 14.3 & 0.33 & -- \\
\hline 1.0 & .3 & 1 & 3 & 3.5 & 1 & 1.5 & 12.5 & 0.53 & -- \\
\hline 1.5 & .6 & 1 & 4 & 2 & 3 & 1 & 13.8 & 0.64 & $?$ \\
\hline 1.0 & .2 & .5 & 2.5 & 3 & 1 & 3 & 13.6 & 0.45 & -- \\
\hline 1.2 & .1 & 1 & 2 & 3.5 & 1.5 & 2 & 13.6 & 0.62 & $t$ \\
\hline
\end{tabular}

ine marked W.T. denotes the approximate position of the present water table. For $<1 \mu \mathrm{m}$ fracions, $\log a / b$ (from Weir and others, 1975) is given as a rough measure of interstratifiation in the smectite. Basal (001) diffraction maxima values are determined after a wet-dry $y c l e$ (see tex $t$ ). " $t$ " refers to trace amounts, " $X$ " means present in significant quantity. 
Many diffractograms indicated the presence of a $7 \AA$ phase; destruction of the peak by heating the sample to $550^{\circ} \mathrm{C}$ identified kaolinite.

Initial X-ray examination of clay fractions suggested that the most distinctive characteristic of the dominant smectite phase was the position of the basal (001) peak. However, because of the swelling characteristics of these clays, this measurement is quite sensitive to humidity. Thus an apparent increase in average (001) spacing for samples obtained from below a depth of $250 \mathrm{~m}\left(820^{\prime}\right)$ was checked by subjecting the $<1$ um smears to a wetting and drying cycle. X-ray examination was given to slides that had been placed in a closed vessel overnight at 100 percent relative humidity, and then air-dried for several hours. The final maxima are given in table 1, and the larger average (001) spacing for samples from deeper than $250 \mathrm{~m}$ is confirmed. Actually, the most uniform (001) spacings are given by smectites from depths between 250 and 300 meters below land surface, arguing against puch water table fluctuation above the present leve1 (302 m depth).

In addition to data on spacing of the (001) smectite reflection the ratio of the intensity of the (001) maxima to low angle (about $3^{\circ} 2 \theta$ ) background was measured. Weir and others (1975) have used the logarithm of this ratio as a measure of the percentage expanding layers in interstratified smectite-illites based on synthetic diffractograms. Though this estimator is not strictly applicable to mixtures of other than pure end-member smectite-illite compositions, the values presented in table 1 appear as further evidence of a difference in clay mineral character toward increased interstratification below $250 \mathrm{~m}$ depth.

In the absence of diagnostic "chain" clay phases, other indications of water table hydration reactions were sought in the approximate quantitative abundance estimates for the lower part of the Ullg core (table 1). These data show three principal features: (1) The highest values for feldspar are above $190 \mathrm{~m}$; (2) zeolite (clinoptilolite) is more prominent below $245 \mathrm{~m}$; and 3) some of the highest clay contents are in core intervals taken near the present water table at about $302 \mathrm{~m}$. The first feature may be related to the contact of younger and older alluvium noted by Carr, and others (1975). The greater quantities of zeolite can be correlated with specific on-site notation of tuffaceous layers in the lower part of the lithologic log for the borehole ( $\mathrm{J}$. R. Ege, written communication, 1971). Though this change can be attributed to more extensive hydrous alteration, it is more likely due to shifts in alluvial provenance. However, more clay below the existing water table argues for the longstanding presence of the water table close to its present elevation. Clay accumulation is consistent with colloidal transport through the unsaturated zone and precipitation near the water table interface.

Optical study of fine sand fractions failed to reveal any systematic differences in state of volcanic glass or its alteration which could be used to corroborate other mineralogic data.

Chemistry

The only bulk chemical measurements previously made on the lower portion of core from $\mathrm{Ullg}$, expl. 1 were moisture content and percent $\mathrm{CO}_{2}$ by acid 
titration (J.R. Ege, written commun., 1971). The bulk moisture content values for the intervals considered here ranged from 4.3 to 11.6 percent and show an overall average correlation with the hydration state of the expandable clay. The percent $\mathrm{CO}_{2}$ ranged from approximately 1 to 17 percent and correlated only very generally with calcite abundance in the intervals analyzed for table 1 . Presumably, the acid titration method could detect cryptocrystalline carbonate not picked up by X-ray diffraction.

Major constituent analysis of $<0.5 \mu \mathrm{m}$ fractions of the $\mathrm{Ullg}$ core samples was undertaken to expand on the mineralogic evidence. The $<0.5 \mu \mathrm{m}$ separarations effectively removed the presumably inert coarse-grained silicate phases (e.g., quartz and feldspar) and the bulk of the carbonate; according to $\mathrm{X}$-ray diffraction the material consisted predominantly of clay minerals and lesser amounts of zeolite. The chemical analyses were performed using modifications of the U.S. Geological Survey rapid rock methods (Shapiro, 1975) for small amounts of sample - acid digestion following fusion with lithium borate. Results are given in table 2. The difference between the total oxides as shown and 100 percent is presumed to be principally water.

Sample intervals selected from the total core suite were processed by high speed centrifugation to obtain a $<0.1 \mu \mathrm{m}$ fraction containing only the smectite clay. The intervals were chosen for abundance of ultrafine material and, within this limitation, a representative range in composition. For these $<0.1 \mu \mathrm{m}$ fractions, major element analysis was performed after repeated shaking of the material in $0.1 \mathrm{M}$ calcium chloride solutions and recovery by centrifuge to obtain exchange capacity and exchangeable ions. These analytical results are given in table 3 .

From the major element chemical analyses of the $<0.5 \mu \mathrm{m}$ fractions it seems that no clear trend in composition with depth can be discerned throughout the intervals examined. However, averages calculated by grouping the samples from above or below $250 \mathrm{~m}$ in depth indicate that the deeper materials are lower in alumina and higher in iron and perhaps magnesium. The same compositional trend was noted in $<0.1 \mu \mathrm{m}$ fractions from the same intervals (table 3 ). Even if the trend is simply a function of grain size, this result is consistent with a smectite component more extensively reacted with ground water.

An attempt was made at more detailed correlation of the major element chemistry in the $<0.5 \mu \mathrm{m}$ separations with the $\mathrm{X}$-ray diffraction data for smectite in the $<1 \mu \mathrm{m}$ fraction. Correlation was sought in terms of individual constituent oxide ratios or phyllosilicate structural combinations with specific basal spacings or differences induced in the wet-dry cycle experiments. The only apparent relationship seemed to be in the increase of $\mathrm{Fe}_{2} \mathrm{O}_{3} / \mathrm{Al}_{2} \mathrm{O}_{3}$ ratio with the decrease in basal spacing fluctuation with humidity noted for samples above $275 \mathrm{~m}$ depth (fig. 1). With one excption, 1ittle or no basal change was noted with $\mathrm{Fe}_{2} \mathrm{O}_{3} / \mathrm{Al}_{2} \mathrm{O}_{3}$ ratio variation below that depth. This correlation can be interpreted as an effect of colloidal iron becoming incorporated in interlayer positions in the smectite and impeding expansion or contraction in basal spacings in response to humidity change. 
Table 2. Major element chemical analyses of $<0.5 \mu \mathrm{m}$ alluvial matrix from borehole Ullg, north of Frenchman Flat, Nevada Test Site. [S.L. Rettig, analyst]

Weight percent, normalized to 100

\begin{tabular}{|c|c|c|c|c|c|c|c|c|c|c|}
\hline \multirow{2}{*}{$\begin{array}{l}\text { depth be- } \\
\text { low land } \\
\text { surface }\end{array}$} & \multirow[b]{2}{*}{$\begin{array}{l}\text { (core } \\
\text { interval) }\end{array}$} & & & & & & & & & \multirow[b]{2}{*}{$\begin{array}{l}\text { Actual per } \\
\text { centage of } \\
\text { tal by wei }\end{array}$} \\
\hline & & $\mathrm{SiO}_{2}$ & $\mathrm{Al}_{2} \mathrm{O}_{3}$ & $\mathrm{Fe}_{2} \mathrm{O}_{3}$ & $\mathrm{CaO}$ & $\mathrm{MgO}$ & $\mathrm{Na}_{2} \mathrm{O}$ & $\mathrm{K}_{2} \mathrm{O}$ & $\mathrm{TiO}_{2}$ & \\
\hline 160.4 & $(2.1)$ & 67.31 & 19.45 & 5.65 & 1.93 & 3.76 & 0.68 & 1.02 & 0.21 & 77.70 \\
\hline 172.2 & $(1.9)$ & 65.81 & 17.88 & 5.62 & 2.98 & 5.11 & 0.61 & 1.60 & 0.39 & 79.72 \\
\hline 184.1 & $(1.4)$ & 63.88 & 13.67 & 5.12 & 6.54 & 6.65 & 0.74 & 2.76 & 0.65 & 75.99 \\
\hline 194.8 & $(0.5)$ & 64.58 & 11.93 & 6.25 & 1.56 & 13.93 & 0.13 & 1.27 & 0.36 & 78.71 \\
\hline 198.1 & --- & 64.81 & 14.25 & 5.58 & 4.21 & 8.48 & 0.65 & 1.58 & 0.43 & 78.38 \\
\hline 199.6 & $(0.5)$ & 66.59 & 14.97 & 6.76 & 2.81 & 7.16 & 0.24 & 1.00 & 0.47 & 78.75 \\
\hline 107.3 & $(0.8)$ & 68.76 & 19.07 & 6.63 & 1.99 & 2.93 & 0.29 & 0.18 & 0.14 & 78.39 \\
\hline 232.5 & $(0.4)$ & 66.73 & 15.66 & 6.63 & 2.35 & 7.35 & 0.29 & 0.72 & 0.28 & 79.20 \\
\hline 243.3 & $(0.5)$ & 65.26 & 14.04 & 6.52 & 1.42 & 11.56 & 0.10 & 0.69 & 0.42 & 79.58 \\
\hline 245.2 & $(0.5)$ & 65.09 & 11.51 & 6.27 & 2.53 & 11.41 & 0.50 & 1.95 & 0.74 & 78.61 \\
\hline 253.4 & $(0.6)$ & 64.63 & 13.37 & 8.59 & 1.97 & 8.69 & 0.44 & 1.66 & 0.65 & 81.74 \\
\hline 262.9 & $(0.9)$ & 64.52 & 12.47 & 8.74 & 1.64 & 9.53 & 0.42 & 1.96 & 0.73 & 81.03 \\
\hline 275.7 & $(0.5)$ & 65.75 & 11.43 & 6.25 & 2.94 & 10.59 & 0.53 & 2.04 & 0.47 & 80.52 \\
\hline 276.5 & $(0.7)$ & 61.08 & 11.94 & 5.08 & 13.28 & 4.80 & 1.31 & 1.95 & 0.56 & 71.25 \\
\hline 284.2 & $(0.8)$ & 63.53 & 11.23 & 6.40 & 2.77 & 13.93 & 0.28 & 1.34 & 0.52 & 74.71 \\
\hline 288.0 & $(0.5)$ & 62.81 & 12.30 & 8.92 & 2.69 & 11.41 & 0.20 & 1.03 & 0.64 & 78.52 \\
\hline 296.6 & $(0.5)$ & 63.83 & 14.09 & 5.77 & 6.84 & 6.46 & 0.56 & 1.91 & 0.53 & 76.91 \\
\hline 305.9 & $(0.5)$ & 69.75 & 14.93 & 4.56 & 2.53 & 4.90 & 0.76 & 2.11 & 0.46 & 80.22 \\
\hline 306.8 & $(1.1)$ & 64.50 & 12.33 & 9.69 & 1.67 & 8.95 & 0.44 & 1.54 & 0.88 & 80.31 \\
\hline 314.0 & $(0.8)$ & 65.07 & 13.35 & 7.86 & 1.93 & 9.07 & 0.31 & 1.67 & 0.74 & 80.24 \\
\hline 329.0 & $(0.2)$ & 64.04 & 16.12 & 6.33 & 2.32 & 8.05 & 0.40 & 1.99 & 0.76 & 78.58 \\
\hline 320.1 & $(1.4)$ & 64.64 & 14.85 & 8.61 & 2.81 & 6.20 & 0.43 & 1.78 & 0.69 & 78.61 \\
\hline \multicolumn{11}{|c|}{ average analyses } \\
\hline above 250 & $\mathrm{~m}$ & 65.88 & 15.24 & 6.10 & 2.83 & 7.83 & 0.42 & 1.28 & 0.41 & 78.50 \\
\hline below 250 & $\mathbf{m}$ & 64.51 & 13.20 & 7.23 & 3.62 & 8.55 & 0.51 & 1.75 & 0.64 & 78.55 \\
\hline
\end{tabular}


Table 3. Major element chemical analyses and cation exchange capacities of $<0.1 \mu \mathrm{m}$ fractions from selected intervals in core of borehole Ullg, Frenchman Flat, Nevada Test Site.

[S.L. Rettig, analyst]

Weight percentage, normalized to 100

\begin{tabular}{|c|c|c|c|c|c|c|c|c|c|c|}
\hline $\begin{array}{l}\operatorname{Depth}(\mathrm{m}) \\
\text { below } 1 \text { and } \\
\text { surface }\end{array}$ & $\begin{array}{l}\text { (core } \\
\text { interval) }\end{array}$ & $\mathrm{SiO}_{2}$ & $\mathrm{Al}_{2} \mathrm{O}_{3}$ & $\mathrm{Fe}_{2} \mathrm{O}_{3}$ & $\mathrm{CaO}$ & $\mathrm{MgO}$ & $\mathrm{Na}_{2} \mathrm{O}$ & $\mathrm{K}_{2} \mathrm{O}$ & $\begin{array}{c}\text { total } \\
\text { anhydrous }\end{array}$ & $\begin{array}{l}\text { CEC in } \\
\mathrm{meq} / 100 \mathrm{~g}\end{array}$ \\
\hline 160.4 & 2.1 & 64.62 & 19.84 & 6.22 & 2.10 & 6.31 & 0.22 & 0.66 & 81.74 & 74 \\
\hline 194.8 & 0.5 & 63.39 & 12.06 & 10.73 & 2.48 & 10.68 & 0.06 & 0.62 & 81.85 & 88 \\
\hline 232.5 & 0.4 & 66.38 & 15.68 & 7.84 & 2.17 & 7.44 & 0.06 & 0.43 & 78.95 & 77 \\
\hline 243.3 & 0.5 & 64.49 & 12.56 & 7.33 & 1.91 & 13.33 & 0.11 & 0.28 & 81.31 & 68 \\
\hline 245.2 & 0.5 & 61.71 & 9.68 & 8.23 & 1.98 & 17.75 & 0.05 & 0.60 & 81.18 & 71 \\
\hline 253.4 & 0.6 & 65.88 & 12.44 & 10.44 & 2.25 & $8 \cdot 31$ & 0.10 & 0.58 & 77.03 & 80 \\
\hline 262.9 & 0.9 & 65.77 & 11.30 & 11.28 & 2.35 & 8.48 & 0.09 & 0.73 & 75.73 & 84 \\
\hline 269.4 & 0.6 & 63.73 & 10.78 & 6.46 & 1.32 & 16.31 & 0.37 & 1.04 & 85.91 & 89 \\
\hline 275.7 & 0.5 & 67.90 & 8.48 & 9.52 & 2.24 & 11.39 & 0.06 & 0.43 & 70.18 & 80 \\
\hline 279.6 & 0.5 & 62.79 & 10.83 & 6.19 & 2.20 & 16.47 & 0.31 & 1.18 & 77.80 & 104 \\
\hline 284.2 & 1.8 & 62.22 & 9.95 & 7.40 & 1.78 & 18.04 & 0.01 & 0.63 & 86.68 & 63 \\
\hline 296.6 & 0.5 & $64 \cdot 50$ & 13.44 & 6.93 & 3.36 & 10.66 & 0.16 & 0.98 & 79.51 & 120 \\
\hline 301.3 & 1.0 & 67.26 & 17.65 & 5.98 & 1.48 & 6.21 & 0.48 & 0.96 & 79.87 & -- \\
\hline 305.9 & 0.5 & 64.41 & 15.50 & 7.02 & 2.42 & 9.86 & 0.14 & 0.66 & 80.25 & 86 \\
\hline 306.5 & 2.0 & 66.08 & 16.15 & 6.56 & 1.74 & 7.78 & 0.49 & 1.18 & 79.67 & 58 \\
\hline
\end{tabular}




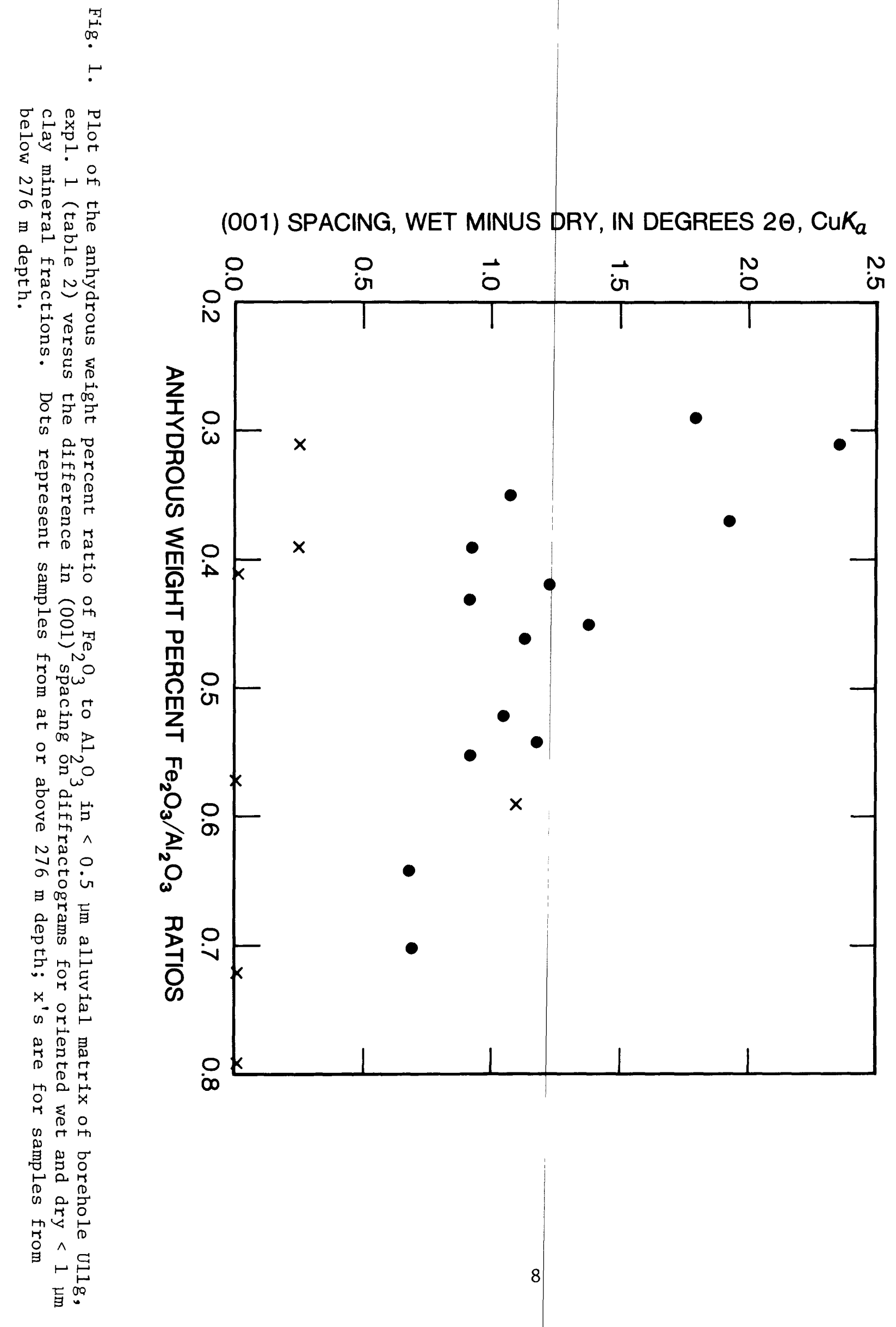




\section{CONCLUS IONS}

Mineralogic study of samples from selected intervals in the alluvial core of borehole Ullg-expl. 1 on the fan north of Frenchman Flat at the Nevada Test site has provided some inconclusive evidence of secondary hydration reactions presumably related to Quaternary stratigraphy or former rises of the water table ranging from 25 to $60 \mathrm{~m}$ above present levels. No evidences of "chain" clays, considered to be indicative of longstanding groundwater saturation, were recognized, but two other lines of evidence are suggestive: 1) greater basal (001) spacings of the smectite clays separated from intervals below $250 \mathrm{~m}$ depth; and 2) more intergrading of the smectite clays associated with greater average iron-content with depth to $275 \mathrm{~m}$; smectite basal peak positions are nearly independent of composition below that level. Unfortunately, features in the overall mineralogy of alluvial fines from the northern Frenchman Flat area, such as increased predominance of zeolite below $245 \mathrm{~m}$ depth, are as likely to be related to depositional hiatus, or subtle shift in provenance as to the effects of former water table rise. However, the relative uniformity of clay hydration (as indicated by basal spacings) throughout the 50 meters above the current water table elevation is consistent with the water table being close to its present position for a long time, perhaps thru most of the Quaternary period.

\section{ACKNOWLEDGMENTS}

Much gratitude is expressed to the following for special assistance: Shirley L. Rettig for chemical analyses, Daniel M. Webster for X-ray diffractometry, Ruth G. Deike for optical mineralogy, and Betty Hudner for manuscript preparation.

Grateful acknowledgement is also given for aid, helpful comment and encouragement to G.C. Doty, I.J. Winograd, R.K. Waddell, and W.E. Wilson. 


\section{REFERENCES}

Carr, W. J., Bath, G. D., Healey, D. L., Hazelwood, R. M., 1975, Geology of northern Frenchman Flat, Nevada Test Site: U. S. Geological Survey Report 474-216, 24 p.

Hay, R. L. and Wiggins, B., 1980, Pellets, ooids, sepiolite, and silica in three calcretes of the southwestern United States: Sedimentology, v. 27, p. 559-576.

Khoury, H. N., 1979, Mineralogy and chemistry of some unusual clay deposits in the Amargosa deserrt, southern Nevada: University of Illinois, Urbana, Ill., $\mathrm{Ph} . \mathrm{D}$. Thesis, $171 \mathrm{p}$.

Klug, H. P. and Alexander, L. E., 1974, X-ray diffraction procedures: 2nd edition, New York, John Wiley, 966 p.

Papke, K. G., 1972, A sepiolite-rich playa deposit in southern Nevada: Clays and Clay Minerals, v. 20, p. 211-215.

Schultz, L. G., 1964, Quantitative interpretation of mineralogical composition from X-ray and chemical data for the Pierre shale: U.S. Geological Survey Professional Paper 391-C, 31 p.

Shapiro, Leonard, 1975, Rapid analysis of silicate, carbonate, and phosphate rocks revised edition: U.S. Geological Survey Bulletin 1401, 76 p.

Singer, Arieh, 1979, Palygorskite in sediments: detrital, diagenetic or neoformed a critical review: Geologische Rund schau, v. 68, p. 996-1008.

Velde, Bruce, 1977, Clays and clay minerals in natural and synthetic systems: New York, Elsevier, $218 \mathrm{p}$.

Weir, A. H., Ormerod, E.C., and E1 Mansey, I. M. I., 1975, Clay mineralogy of sediments of the western Nile delta: Clay Minerals, v. 10, p. 173-187.

Winograd, I. J. and Doty, G. C., 1980, Paleohydrology of the southern Great Basin, with special reference to water table fluctuations beneath the Nevada Test Site during the Late(?) Pleistocene: U.S. Geological Survey Open-file Report $80-569,91 \mathrm{p}$.

Winograd, I. J. and Thordarson, William, 1975, Hydrogeologic and hydrothermal framework, south-central Great Basin, Nevada-California, with special reference to the Nevada Test Site: U.S. Geological Survey Professional Paper 712-C, p. $\mathrm{Cl}-\mathrm{Cl} 26$. 